\title{
Defending the Criminal Law: Reflections on the Changing Character of Crime, Procedure, and Sanctions
}

\author{
Andrew Ashworth $\cdot$ Lucia Zedner
}

Published online: 4 August 2007

(c) Springer Science+Business Media B.V. 2007

\begin{abstract}
Recent years have seen mounting challenge to the model of the criminal trial on the grounds it is not cost-effective, not preventive, not necessary, not appropriate, or not effective. These challenges have led to changes in the scope of the criminal law, in criminal procedure, and in the nature and use of criminal trials. These changes include greater use of diversion, of fixed penalties, of summary trials, of hybrid civil-criminal processes, of strict liability, of incentives to plead guilty, and of preventive orders. The paper will assess the implications of these changes for the function of the criminal law, assessing the reasons behind them, and examining whether or not they are to be welcomed. Identifying the larger import of these changes draws attention to the changing relationship between state and citizen as well as changes in the nature of the state itself. These can in turn be attributed to a jostling among the different manifestations of the authoritarian state, the preventive state, and the regulatory state. These changes have profound normative implications for a liberal theory of the criminal law that require its re-articulation and its defence. A modest start may be to insist that where the conduct is criminal and the consequences are punitive the protections of criminal procedure and trial must be upheld.
\end{abstract}

Keywords Criminal law $\cdot$ Criminal procedure $\cdot$ Criminal trial $\cdot$ Prevention

\section{Introduction}

The scope and functions of the English criminal trial have changed over the centuries, but the pace of change appears to have quickened in the final quarter of the last century and this acceleration is continuing. There is ample evidence that some longstanding

\footnotetext{
A. Ashworth $(\square)$

All Souls College, University of Oxford, Oxford OX1 4AL, England e-mail: andrew.ashworth@law.ox.ac.uk

L. Zedner

Corpus Christi College, University of Oxford, Oxford OX1 4JF, England

e-mail: lucia.zedner@law.ox.ac.uk
} 
assumptions about the role and the place of the criminal trial and, it follows, the criminal law are under challenge. This paper sets out on a preliminary exploration of the changing purpose of the English criminal trial and the changing character of the criminal lawpreliminary, because the issue quickly reveals itself as complex and multi-layered. A fundamental premise is that the shifting nature of the criminal law is bound up with certain changes in the nature and use of criminal trials. This close connection between criminal law and criminal procedure has long been apparent, not least since Glanville Williams concluded over 50 years ago that there could be no substantive definition of crime and that 'a crime is an act capable of being followed by criminal proceedings having a criminal outcome.' ${ }^{1}$ Similarly Antony Duff and colleagues, in their ongoing exploration of the criminal trial, argue that the theory of criminal law has intimate normative connections with the theory of the criminal trial and theories of state punishment. ${ }^{2}$ Thus we begin our paper with a construct of a liberal model of the criminal law and the criminal trial that may be thought to owe more to liberal aspirations than to history or contemporary reality. It might take the following form:

The purpose of criminal law is to provide for the censure and sentencing of those who commit wrongs that have been (justifiably) criminalised. No person should be liable to conviction and/or punishment unless the charge has been duly tried in a criminal court according to the procedural safeguards expressed and implied in the European Convention of Human Rights. The purpose of the criminal trial is to have an examination, by a court sitting in public, of the admissible evidence brought by the prosecution and by the defence, in order to decide whether the defendant did the act charged and, if so, was at fault for doing it.

Underlying this paradigm is a liberal conception of criminal justice that emphasises both the purpose of the criminal law in providing for censure and punishment and the need to respect the autonomy and dignity of individuals in the criminal process. ${ }^{3}$ At a minimum, therefore, the trial should be fair, in terms of the appropriate procedural safeguards (now those in the European Convention, as well as at common law), and the official censure of conviction and punishment is only justifiable if there has been a trial observing those safeguards.

This paradigm and its implications have come under increasing challenge in recent years. This is not to suggest that the legislature has turned away from the 'traditional' criminal law: on the contrary, over 3,000 new offences have been enacted in England since the Labour government came to power in $1997 .{ }^{4}$ But some of these offences do not conform to the paradigm and, as we will show, the government has been seeking ways of suppressing conduct without invoking the criminal law. Our purpose here is to reflect on the changing role of the criminal law in the modern state, and we argue that this is partly bound up with growing scepticism about the fitness of the criminal trial to fulfil its

\footnotetext{
${ }^{1}$ Williams, G. (1955). The definition of a crime. Current Legal Problems, 107-130.

2 Duff, A., Farmer, L., Marshall, S., \& Tadros, V. (2004). Introduction: Towards a normative theory of the criminal trial. In Duff, Farmer, Marshall, \&Tadros (Eds.), The trial on trial (Vol. 1). Oxford: Hart Publishing, at 11 and 17.

${ }^{3}$ For discussion of the fundamental role of the concept of dignity, see Roberts, P. (2006). Theorising procedural tradition: Subjects, objects and values in criminal adjudication. In Duff, Farmer, Marshall, \& Tadros (Eds.), The trial on trial (Vol. 2) Oxford: Hart Publishing.

4 Between 1997 and 2006, some 3,000 new offences were created, 1,169 in primary legislation and 1,854 in subordinate legislation: Daily Mail, '3,000 new criminal offences created since Tony Blair came to power', 16 August 2006. http://www.dailymail.co.uk/pages/live/articles/news/news.html?in_article_id= 400939\&in_page_id=1770
} 
purposes. $^{5}$ At this stage we will outline five avenues of challenge to the paradigmatic sequence of prosecution-trial-conviction-sentence:

(a) Not cost-effective: it is argued that, as the cost of trials rises, they are not a costeffective means of fulfilling their purpose. Jury trials should therefore be reserved for the most serious charges where the defendant pleads not guilty, and even summary trials should be reserved for cases in which a court hearing really is necessary.

(b) Not preventive: it is argued that bringing a defendant to court, with a view to conviction and sentence, may not have preventive effects and may even be counterproductive. This has been a prominent argument in youth justice, where the experience of being accused in court may reinforce a youth's self-identification with lawbreakers and impose the stigma of conviction. It also appears that for some adult offenders conviction and sentence have no greater preventive effect than a form of diversion. This challenge assumes that the purpose of the criminal law and its processes is preventive, at least to some degree.

(c) Not necessary: it is argued that court proceedings are unnecessary where the defendant is willing to plead guilty, and that for some lesser forms of offending a court hearing may not need to examine the defendant's fault or may not be necessary at all for minor offences, since almost all defendants are willing to accept some lesser, swifter resolution of the case.

(d) Not appropriate: it is argued that the criminal trial is not well suited to dealing with ongoing conduct and continual offending, because it focuses on specific charges without examining broader issues and continuing patterns of misconduct.

(e) Not effective: it is argued that in some cases it may not be possible to have a trial, if the canons of procedural fairness are observed, because witnesses are likely to be in fear or otherwise reluctant, and the charge will therefore have to be dropped. For some kinds of crime, high attrition rates (i.e., a low proportion of detected cases going to trial) suggest that aspects of criminal procedure may have the effect of preventing some defendants from being brought to trial.

The first seven parts of this paper explore some of the different ways in which these challenges have led to changes in the English criminal trial in recent years. The aim of this analysis is not to be comprehensive but to outline some major trends that call for recognition, explanation and justification. Whilst it may be that larger patterns can be derived from these changes we treat them separately, initially at least, in order to tease out the particular whys and wherefores of each development before essaying later in the paper some broader explanations of the changes and their implications. The seven major trends selected for analysis are those towards greater use of:

(1) diversion

(2) fixed penalties

(3) summary trials

(4) hybrid civil-criminal processes

(5) strict criminal liability

(6) incentives to plead guilty

(7) preventive orders.

\footnotetext{
${ }^{5}$ For exploration of the purposes of the criminal trial, see the two volumes by Duff, Farmer, Marshall and Tadros cited in notes 2 and 3 above. A third volume is yet to come.
} 
In respect of each of these, the paper will assess whether there is increased resort to the particular strategy; what its implications are for the role of the criminal law and the purpose of the criminal trial; what reasons lie behind its greater use; and whether the development is to be applauded or not. Part 8 of the paper considers the implications of these changes for the role of the state in England and Wales, and for different forms of governance. Part 9 assesses the normative significance of these changes, and seeks to elaborate and defend a liberal conception of the criminal law that shows many of the changes to be objectionable in principle.

\section{Substantive Changes}

\section{Greater Use of Diversion}

There is little doubt that the use of diversion increased during the final quarter of the last century. The principal means of diverting defendants from prosecution throughout this period was the formal police caution, and the official statistics record that some 109,000 persons were cautioned rather than prosecuted in 1971 , rising to some 230,000 persons in $2001 .^{6}$ That is more than a twofold increase, and may be compared with the decline in convictions over the same period from 1.7 million to 1.5 million. The increase in diversion has not been linear, since the cautioning rate reached its peak in the early 1990s and subsequently fell back a little; but the figures for 2004 show that diversion is rising again, and in any event the cautioning rate is still more than double that of 30 years ago. Further legislative changes in recent years may be having an impact. In 1998 the Crime and Disorder Act replaced the police caution for young defendants with reprimands and final warnings, a more structured framework that appears to have been used only a little less widely than the police caution in earlier years. ${ }^{7}$ Where the youth is given a warning, the police refer the case to the local Youth Offending Team, which should then arrange for the youth to participate in a rehabilitation programme unless they think this inappropriate. The result is that this form of 'diversion' imposes the quasi-penal burden of a rehabilitative programme notwithstanding the fact that the young person has not been brought to trial.

Turning to adults, the Criminal Justice Act 2003 introduced the conditional caution, which may be given by the Crown Prosecution Service to a person who admits the offence and agrees to the stipulated conditions. These may include participation in some rehabilitative, reparative or restorative programme. ${ }^{8}$ No clear pattern in the use of conditional cautions has yet appeared, but it is important to note that, whereas the system of reprimands and warnings for youths replaces police cautions, the conditional caution for adults has not replaced police cautions. It remains open to the police to administer a "simple caution' when they think it fit. Add to this the wide scope that continues to exist, in respect of both youths and adults, for the police to caution people informally for offending behaviour, then English law and practice provides considerable opportunity for diversion from court.

\footnotetext{
${ }^{6}$ Criminal Statistics 2003, Table 1.1.

7 See further Fionda, J. (2005 ). Devils and angels: Youth policy and crime. Oxford: Hart Publishing, chap. 5.

${ }^{8}$ See further Ashworth, A., \& Redmayne, M. (2005). The criminal process (3rd ed.). Oxford: Oxford University Press, pp. 159-161.
} 
What are the implications of these developments? The principal impact is to relieve the courts of hearing many cases that would have to be dealt with if there were a system of compulsory prosecution. However, few countries even maintain the fiction of compulsory prosecution any longer: what is termed 'the principle of opportunity' in continental Europe (i.e., a discretion not to prosecute) is widely accepted, and has resulted in various forms of diversion in different countries. ${ }^{9}$ Nonetheless, it remains true that many cases that could be brought to court are not. On the one hand this spares the person the label, stigma and other legal and social disadvantages that might attach to a conviction, and offers the person the opportunity to respond to the experience of formal diversion by adjusting his or her behaviour. Prosecution in court may be a disproportionate response to some lesser offences, and the so-called 'justice gap' (signified by the high rate of attrition) may in part be the product of the legitimate diversion of less serious cases where this allows swifter and less costly forms of resolution. On the other hand an offer of diversion constitutes a temptation to admit an offence and to forgo the formal safeguards of a court hearing in order to ensure that no conviction follows. Whether this is fairly described as a temptation or in some circumstances as coercion is for discussion. All forms of diversion depend on the person's consent, so that in theory there is always the option of refusing to accept the diversion and thereby challenging the prosecutor to bring the case to court, but if the perceived disparity between the two courses is great, might not temptation shade into coercion? Generally conceived of as a benign aspect of the criminal process, diversion is not without drawbacks. The practice of diversion compromises the right of defendants to be presumed innocent, relieves the prosecution of the burden of proving guilt, and may bring intolerable pressure to bear upon those eager to escape the police station or fearful of the prospect of prosecution to admit an offence they may not have committed. Where this admission is followed by further burdensome consequences, be it participation in rehabilitation programmes or restorative justice conferences, the costs of diversion are even greater.

What reasons lie behind the greater use of diversion? The answer to this question is complex and multi-faceted. In one direction lies the cluster of fiscal and managerial considerations to which the Council of Europe gave prominence when advocating the increased use of diversion - the need to concentrate resources on the trial of serious crimes, the need to reduce overall pressure of the court system, and the need to avoid delay and to provide more timely responses to offending behaviour (which may also be in the interests of victims). ${ }^{10}$ In another direction lie various considerations that recognize the interests of those who offend either for the first time or in a minor way, particularly the young. The formal machinery of the criminal law may be a disproportionate response to such offending, and a court appearance, with its attendant publicity, may even be counterproductive (in terms of labelling, reinforcement of identity as an offender, and contact with other offenders). The reduction of delay, listed above as a managerial consideration, also redounds to the advantage of the defendant in many cases: indeed, the European Convention on Human Rights contains both a right to be brought before a court without undue delay and a right to trial within a reasonable time. ${ }^{11}$ Since it can also be claimed that

\footnotetext{
9 See Ashworth and Redmayne, ibid., chaps. 6 and 7, and Fionda, J. (1995). Public prosecutors and discretion: A comparative study. Oxford: Oxford University Press.

${ }^{10}$ Council of Europe, The Simplification of Criminal Justice, R (87) 18 (1988).

11 See Ashworth and Redmayne (above, n. 3), 249-260. Though it is arguable that diversion deprives its subjects of both these in order to minimize delay for others.
} 
diversion tends to be followed by fewer convictions than court sentences, ${ }^{12}$ it seems that the reasons for promoting diversion consist of a healthy combination of public interest with the interests of defendants. Whether they favour the interests of victims is more difficult to say since diversion deprives victims of their day in court, but one of the purposes behind the introduction of reprimands and warnings for youths and of conditional cautions for adults is to enhance the probability of reparation to the victim. ${ }^{13}$

Is the expansion of diversion to be welcomed? A preliminary point concerns the genuineness of the expansion: the question cannot be answered sensibly unless it is clear that the expansion is not simply what criminologists call 'net-widening', ${ }^{14}$ i.e., that these are people who would not have been prosecuted anyway. Presuming this is verified, the answer to the question then depends on the criteria for making such a judgment. The first three of the challenges set out at the beginning of the paper are relevant here. Challenge (a) would suggest that criminal proceedings should be reserved for non-minor offences, and that first offenders of some moderately serious offences may properly be diverted from court if their age (young or old) or other factors point in that direction. This derives from the view that court proceedings are solemn, costly, public occasions that should not be used unnecessarily. Challenge (b) would suggest that criminal proceedings should not be used if there is good reason to believe that they may have a crime-productive rather than a crime-reductive effect. This harks back to the belief that prosecution in court may have effects of labelling and stigmatising certain people, particularly young offenders, to the extent of increasing their chances of further lawbreaking. Any such considerations must be subject to countervailing principles, such as that very serious charges ought to be taken to court even if the defendant has no record of previous offending-although this remark is made in the context of the English youth justice system, and should not be taken to suggest that that system is to be preferred to others (such as the Scottish) which deal with serious offences in children's hearings rather than courts. ${ }^{15}$ And challenge (c) returns to the economic aspect of challenge (a), suggesting that a court hearing is unnecessary when most defendants would accept a diversionary disposal. Given the considerable imbalance of power between the police and the suspect, however, the consensual basis of diversion is, at least in some cases, open to doubt. If diversion does not rest upon freely given consent its compatibility with elementary notions of justice is questionable. Even where consent is freely given, diversion of cases above a certain level of seriousness should be opposed, insofar as it permits a private negotiation between defendant and state to trump the larger public interest in proportionate penal responses and replaces public prosecution with an individualized, private form of justice or 'contractual governance'. ${ }^{16}$

\section{Greater Use of Fixed Penalties}

Fixed penalty fines, payable without any court appearance, have long been used for the less serious road traffic offences. Parking offences are an obvious example, but more significant

\footnotetext{
12 Ashworth and Redmayne (above, n.3), ch. 7.

${ }^{13}$ Hoyle, C., \& Zedner, L. (2007). Victims, victimization and criminal justice. In Maguire, Morgan, \& Reiner (Eds.), The Oxford handbook of criminology (pp. 484-486). Oxford: Oxford University Press .

14 Cohen, S. (1985). Visions of social control. Cambridge: Polity Press.

15 For an accessible discussion, see Fionda (above, n. 2), 245-252.

${ }^{16}$ Crawford, A. (2003). Contractual governance' of deviant behaviour. Journal of Law and Society, 30, 479-505.
} 
since 1988 are the various moving traffic offences, such as speeding and failure to comply with traffic signs, some of which carry penalty points. ${ }^{17}$ The offender is required to pay the fixed penalty and to produce the licence for endorsement (where applicable). A similar power is now available more widely: the Penalty Notice for Disorder (PND) is a penalty, issued by the police on the spot, of either $£ 50$ or $£ 80$ depending on the offence. ${ }^{18}$ The name suggests that such notices may only be issued for offences against public order, such as threatening behaviour or causing harassment, alarm or distress, but the list includes theft from a shop of goods up to the value of $£ 200$. It seems that over 100,000 such notices were issued by police in 2005 , of which about $14 \%$ were for theft from a shop. ${ }^{19}$

Fixed penalties are clearly being used more than formerly, but what are the implications of this? To some extent they relieve the magistrates' courts of having to deal with a number of less serious offences, but we should also recognize the possibility of net-widening here. The police may well issue a PND for theft in circumstances where they would not have been prepared to prosecute. It is open to the recipient of a PND to contest the notice in court, but that takes energy and in some cases there may be a tendency to pay the money in order to bring the matter to an end. However, the difference between fixed penalties and diversion itself is that the former may have penal consequences. If a particular motoring offence carries penalty points, those must be recorded. A person who is given a PND and pays the fine does not receive a criminal conviction, although the fact of the PND is recorded. ${ }^{20}$ The recording of penalties, although it falls short of conviction, nonetheless generates a grey area of classification that may have adverse implications in the future for those so categorized. PNDs are enforced as fines, only 51\% are paid, and default may ultimately result in imprisonment.

What reasons lie behind the expansion of fixed penalties? The main driving force has been economic. In road traffic offences there has been an understandable desire to relieve the courts of having to deal with cases that are easily proved and frequently not defended, and where penalties can be standardized. For the PND the primary objective was to relieve the police from having to prepare statements and appear in court for offences that amounted merely to low-level disorder. Dealing with these offences on the spot may be seen as saving police time, perhaps bringing some finality to an incident, and even connecting the punishment more closely with the offence committed. ${ }^{21}$ That efficiency arguments lie at the heart of PNDs can be deduced from the evidence collected by the government that issuing a PND results in a saving of between 1.5 and 2.5 hours of police time as compared with that required for a caution or prosecution. ${ }^{22}$

Is the expansion of fixed penalties to be welcomed? In principle, some of the arguments in favour of diversion apply equally here. Challenges (a) and (c) suggest that, since most of the relevant offences are not serious enough to require formal court proceedings and most defendants will accept a fixed penalty, there are good reasons of economics and proportionality for not using full court hearings for these cases. But there are potential difficulties.

\footnotetext{
17 Road Traffic Offenders Act 1988, Schedule 3.

18 Criminal Justice and Police Act 2001 ss.1-11.

19 Sentencing Advisory Panel Consultation Paper on Theft from a Shop (2006) p. 5 http://www.sentencingguidelines.gov.uk/docs/cons-annex-theft-0806.pdf

20 The PND is recorded against the offender's name on the Police National Computer, so that if the offender is involved in further similar behaviour the fact of the previous PND should be revealed.

21 See von Hirsch, A., Bottoms, A. E., Burney, E., \& Wikstrom, P.-O. (1999). Criminal deterrence and sentence severity: An analysis of recent research. Oxford: Hart Publishing.

${ }^{22}$ Home Office RDS Findings No.257 (London: Home Office 2004) 1.
} 
One is that fixed penalties may have a net-widening effect, in the sense that they may result in the punishment of some people who would not have been prosecuted otherwise. Evidence from a government pilot study suggests that between a quarter and a half of PNDs are imposed upon offenders who would otherwise have been cautioned or prosecuted, suggesting that a majority of those receiving PNDs may previously have fallen outside the criminal justice net. ${ }^{23}$ On the other hand, it could be argued that some widening of the net may be fully justified. Police and prosecutors have declined to prosecute some shoplifters because the cost of doing so is disproportionate, with the result that some offenders have escaped scot-free, and it is therefore right to devise a more efficient way of responding to such offences. Another potential difficulty is that fixed penalties may be set at a level that is beyond the means of some people. The $£ 80$ PND for theft from a shop, for example, may be overly burdensome for someone on state benefits who has a low income or onerous outgoings. In this context the person who has received a PND must opt for a court hearing, and then trust the court to calculate the fine so as to take account of his or her means. The fact that courts have a duty to take into account the means and outgoings of the defendant reveals that which the fixed penalty system is sacrificing to efficiency: a fixed penalty is a regressive tax capable of doing injustice in the individual case.

\section{Greater Use of Summary Trials}

The transfer of business from the Crown Court to the magistrates' courts has formed part of the criminal justice policy of all recent British governments. The existing system is that some crimes are triable only on indictment (in the Crown Court with a jury), some are triable only summarily (in the magistrates' courts), and there is an intermediate category of offences triable-either-way, for which either the defendant can elect or the magistrates can require trial in the Crown Court. In recent years many crimes have been downgraded from triable-either-way to summary offences, so as to remove the option of Crown Court trial, notably by the Criminal Law Act 1977 and by the Criminal Justice Act 1988. While offences such as drunk driving, driving whilst disqualified, taking a car without consent and common assault are among those removed from the Crown Court and made summary only, several attempts to achieve a similar removal of small-value thefts have failed. ${ }^{24}$ The Criminal Justice Act 2003, if implemented, will double the maximum severity of sentences that magistrates' courts can impose, from 6 months to 12 months for a single offence, and this would undoubtedly have the effect that fewer cases would go up to the Crown Court. The practical effect of these initiatives has been to reduce the number of defendants tried at the Crown Court from some 100,000 in 1991 to some 77,000 in 2001, although since then there has been a slight rise to 80,000 in 2003 .

What are the implications of this shift of business away from the Crown Court? From one point of view there have been considerable economic benefits. Costs are being controlled, since the more expensive mode of trial is being effectively reserved for the most serious cases. More cases are being dealt with in the magistrates' courts, which are cheaper, swifter and have tended to impose lower sentences than the Crown Court. On the other hand, the right to trial by jury has been progressively reduced. Some regard that right as fundamental, although it is not recognized by the European Convention and the extent of

\footnotetext{
23 Home Office RDS Findings No.257 (London: Home Office 2004) 1.

${ }^{24}$ For discussion of these developments, see Ashworth and Redmayne (above, n. 3), 297-314.
} 
the right (i.e., the offences to which it should be attached) has always been controversial. More worrying are the repeated findings that court users have much less confidence in magistrates' courts than in the Crown Court, citing the speed at which proceedings are conducted and the tendency to appear to favour the prosecution. ${ }^{25}$

The reasons for these changes in the law of mode of trial are similar to those for the increases in diversion and fixed penalties, and (as we will see in 6 below) guilty pleas. Challenges (a) and (c) are much to the fore, with economic reasons often cited. The implication is that the criminal trial is an expensive process, and that it should be reserved for the cases in which it is really necessary. But others may infer that more sinister motives predominate, notably a desire to reduce reliance upon the vagaries of jury trials, and instead allocating more cases to the magistrates' courts, which have either lay tribunals that are much less socially representative than juries or judge-only tribunals in which district judges (formerly stipendiary magistrates) take the decisions.

Whether the confinement of Crown Court trial and the spread of summary justice are to be welcomed depends on a complex analysis of conflicting considerations. If one looks across Europe then jury trial, or the most solemn form of procedure, is everywhere restricted to a small number of serious offences; and in few countries does the defendant have a right to choose the forum. The additional argument in England and Wales concerns the questionable quality of summary justice, an argument that has repeatedly won the day when it has been proposed to make small-value thefts triable summarily only. If it were established that the substance of the procedural safeguards in the Convention is not respected in magistrates' courts, then that would be a strong argument against the trend, whether or not it is economically driven. Others would mount the alternative argument that it is juries that are unreliable, unpredictable and sometimes gullible and/or unable to understand the case. It is strongly arguable that the common law trial's emphasis on orality fits poorly with cases that rely on voluminous documentary evidence. ${ }^{26}$ The last argument, about the complexity of some cases, has been much discussed since the Roskill Report in 1985 on fraud trials, and section 43 of the Criminal Justice Act 2003 now makes provision for certain cases of 'serious and complex fraud' to be tried by judge alone, although the provision has not yet been implemented.

\section{Greater Use of Hybrid Civil-Criminal Processes}

A new arrival in English law is what may be termed the hybrid civil-criminal process. The essence of this new device is that a civil order is made in civil proceedings, restraining the subject's behaviour in specified ways, and breach of the civil order constitutes a criminal offence with a substantial maximum penalty. There are two principal examples. Under the Crime and Disorder Act 1998 magistrates may make an Anti-Social Behaviour Order (ASBO) if satisfied that the defendant has engaged in behaviour that has caused, or is likely to cause, harassment, alarm or distress to others, and that the order is necessary to protect people from further such acts. The ASBO may prohibit the person from doing anything that might expose people to further anti-social acts, and must last for at least 2 years. Breach of

\footnotetext{
25 Ibid, at 299-300.

26 See the comparative discussion by Weigend, T. (2006). Why have a trial when you can have a bargain. In Duff, Farmer, Marshall, \& Tadros (Eds.), The trial on trial (Vol. 2). Oxford: Hart Publishing, at 210.
} 
the ASBO without reasonable excuse is an offence with a maximum penalty of 5 years' imprisonment. ${ }^{27}$ The second example is breach of a non-molestation order. A family court, typically the County Court, may make a non-molestation order prohibiting the defendant from, for example, entering or going near a certain residence. Breach of the order without reasonable excuse is now an offence with a maximum penalty of 5 years' imprisonment. ${ }^{28}$

What are the implications of the spread of these hybrid orders? One clear consequence is that matters that might otherwise be dealt with as criminal offences may now be treated as breaches of an order and may even result in the imposition of a more severe sentence than would have been possible for the offence itself. ${ }^{29}$ For example, neither begging nor soliciting for prostitution is an imprisonable offence, no matter how many times it is committed. But if it is a condition of an ASBO that the defendant should not beg or solicit on the street, breach of the order may result in imprisonment. ${ }^{30}$ In these cases, moreover, the imposition of the order results from civil proceedings conducted under civil rules of evidence, without the safeguards provided by the European Convention on Human Rights for criminal proceedings. The House of Lords turned down the argument that the proceedings were in substance criminal, according to the Convention, but held nevertheless that a standard of proof equivalent to that in criminal proceedings should be required. ${ }^{31}$ However, it is still a concern that the principal evidence in such cases can be untested hearsay. Other matters of concern include the fact that these orders may target low levels of nuisance well below the normal threshold of the criminal law; that the conditions they impose are potentially disproportionate in such cases; and, at the same time, that there is little to stop these orders being used relatively high up-tariff where prosecution would be more appropriate.

What reasons lie behind the introduction of these hybrid orders? The main reason is dissatisfaction with criminal procedure and the criminal trial. Challenge (d) suggests that the criminal trial is unsuited to dealing with ongoing offensiveness, and challenge (e) suggests that the procedural requirement that the witness confront the defendant operates to discourage prosecutions. In relation to the ASBO, however, much depends on the definition of anti-social behaviour or, more precisely, on whether it must be behaviour that is not otherwise criminal (sometimes termed 'nuisance behaviour') or may be conduct that is already criminalized. ${ }^{32}$ One infers that the answer is that both were intended to be included, since orders have been made to prohibit noisy trampolining, swearing at neighbours, and burglary, robbery and theft. Conduct that amounts to an offence could be prosecuted and sentenced through an ordinary criminal trial, but a significant feature of the ASBO is its authoritarian assumption that any breach of the order by repetition of the

\footnotetext{
27 Ashworth, A. (2004b). Social control and anti-social behaviour order: The subversion of human rights? Law Quarterly Review, 120, 263-291.

28 Domestic Violence, Crime and Victims Act 2004, s.1: for proposed sentencing guidelines, see Sentencing Guidelines Council, Breach of a Protective Order (Consultation Guideline) (London: Sentencing Guidelines Council, 2006). Further examples are discussed in part 7 below, in the context of preventive orders.

29 Simester, A. P., \& Von Hirsch, A. (2006). Regulating offensive conduct through two-step prohibitions. In Von Hirsch \& Simester (Eds.), Incivilities: Regulating offensive behaviour. Oxford: Hart Publishing.

30 See now the guideline decision in Boness and Bebington [2006] Crim.L.R. 160, which leaves open the possibility of a sentence more severe than the maximum for the offence; cf. H., Stevens and Lovegrove [2006] Crim.L.R. 569.

31 Clingham v. Royal Borough of Kensington and Chelsea; R (McCann) v. Manchester Crown Court [2003] 1 AC 787.

32 See Ramsay, P. (2004). What is anti-social behaviour? Criminal Law Review, 908-925.
} 
behaviour must result in a substantial penalty. This is manifestly criminalization of defiance of the law, not punishment for the originating nuisance, and it is questionable whether these penalties are proportionate to breach alone. ${ }^{33}$ When the Bill creating ASBOs was originally presented to Parliament, it provided for a maximum sentence of 7 years and a minimum sentence of 12 months for breach, but Parliament reduced the former and removed the latter. The Government's expressed commitment to reducing anti-social behaviour-howsoever that is defined-leads it continually to urge the courts to use ASBOs.

Are hybrid orders to be welcomed? Even if it is accepted that there is substance in challenges (d) and (e) here, the new procedure gives rise to wide-ranging objections. The basic concept of anti-social behaviour is too vague and elastic, ${ }^{34}$ and contravenes the ruleof-law principles of certainty and fair warning; the conditions imposed can be wideranging and disproportionate; the hybrid procedure treats the two sets of proceedings (imposition, breach) as entirely separate when in substance they are not and therefore defendants should be entitled to the same safeguards as in criminal proceedings; and sentences can be disproportionate to the nature of what has been done and place too much emphasis on the fact of breaching the order. In practice, some $45 \%$ of ASBOs are breached, a consequence in part of the burdensome nature of the conditions imposed and the failure to provide support or help in meeting them. Over half of those convicted of breach are subjected to a custodial sentence, i.e., imprisonment or (for young offenders) detention. Where the original order was made in respect of a non-criminal nuisance, or one (such as begging or soliciting for prostitution) that is criminal but non-imprisonable, it can be argued that the use of custody is wrong in principle. Serious cases of breach, on the other hand, could usually be dealt with under the general criminal law. ${ }^{35}$ Since about half of all ASBOs have been made on children-although the Government initially said that the ASBO was not intended for the young - this raises important issues of justice: although the custody rate for children is lower, the vast majority of young offenders sent to custody re-offend. It must be concluded, therefore, that hybrid orders like the ASBO are intended to lead to the decline of the criminal trial, by taking some cases away from that procedure and placing them in this hybrid category. A powerful basis for objection here is that noncriminal proceedings should not be used to circumvent the criminal trial if the outcome can be a significant penalty, especially (but not exclusively) ${ }^{36}$ if it may entail loss of liberty.

\section{Greater Use of Strict Liability}

Liability may be termed 'strict' where an offence is so defined as not to require the prosecution to prove any fault (intention, recklessness or negligence) on the part of the defendant; in some instances the legislation itself may clearly impose strict liability, in

\footnotetext{
33 Von Hirsch, A., \& Roberts, J. (2004). Legislating sentencing principles: The provisions of the criminal justice act 2003 relating to sentencing purposes and the role of previous convictions, Criminal Law Review, 639-652.

34 Von Hirsch, A., \& Simester, A. P. (Eds.) (2006). Incivilities: Regulating offensive behaviour. Oxford: Hart Publishing, especially chaps. 2 and 6.

35 E.g., Braxton [2005] 1 Cr App R (S) 167; cf. the guidance on sentencing for breach of an ASBO laid down in Boness and Bebington and Morrison (above, n. 21).

36 Cf. the extensive powers in sections 240-241 of the Proceeds of Crime Act 2002 for the making of 'recovery orders' against persons who have not been convicted in respect of whom the civil court is satisfied that they possess property obtained through unlawful conduct.
} 
others the courts will have to decide whether to apply the 'constitutional principle' of no criminal liability without fault to a statutory offence, and may find reasons for not doing so. ${ }^{37}$ This working definition of strict liability may be extended to include offences where it is open to the defendant to avoid liability by establishing that there was no fault, although some would prefer to regard such offences as violations of the presumption of innocence rather than examples of strict liability.

Are offences of strict liability increasing? Such offences did not appear in English law in significant numbers until the mid-nineteenth century, so one can clearly say that there are more such offences than two centuries ago. Even if we focus on the final quarter of the last century, the trend seems to be evident. Over 3,000 new criminal offences have been created since the present Government came to power in $1997^{38}$ and it seems likely that a substantial proportion of them are offences of strict liability. Thus in 2005 around one-third of all new criminal offences contained at least one strict liability element. ${ }^{39}$ These are not merely so-called regulatory offences, penalising failures to comply with financial or industrial regulations, but also offences carrying a maximum of life imprisonment. Thus sections 5 and 6 of the Sexual Offences Act 2003, creating the offences of rape and sexual penetration of a child under 13 (punishable with a maximum of life imprisonment), were intended to impose strict liability as to age. ${ }^{40}$ Strict liability in respect of the age of children under 13 is also imposed by a number of 'child sex offences' that carry maxima of up to 14 years' imprisonment. ${ }^{41}$ Whether strict liability is exceptionally justified in all such cases is for debate elsewhere. The point here is that there are elements of strict liability in offences triable in the Crown Court and carrying substantial maximum penalties, ${ }^{42}$ in addition to the increasing number of summary offences that impose strict liability.

What are the implications of this continued development? Strict liability makes it easier for the prosecution to obtain a conviction, and therefore has economic advantages in expediting the criminal process, although the prosecution may have to establish fault at the sentencing stage if it is contested by the defence. ${ }^{43}$ For the defendant, however, strict liability means that a conviction may be recorded even though no fault was proved. Indeed, not only may the stain of a conviction be imposed, but also a significant sentence-even a custodial sentence-may be the result. Thus strict liability raises deep questions about the proper position and social meaning of the criminal trial. Should the defendant's culpability always be a focus of the trial, or can this issue be dispensed with (as where liability is strict)? Is it right to label a person a criminal, if on a key element there is no need to prove

37 Authority for this 'constitutional principle' may be found in B v. D.P.P. [2000] 2 AC 428 and in K. [2002] 1 Cr App R 121; cf. A. Ashworth, Principles of Criminal Law (5th ed 2006), 164-174, for discussion of judicial reasons for not applying the principle.

38 See footnote 4.

39 'Criminalization: what do 2005's new crimes tell us about the law?', unpublished ms., A. Ashworth.

40 Rook, P., \&Ward, R. (2004). Sexual offences: Law and practice; G. [2006] EWCA Crim 821, [2006] Crim.L.R. 930.

41 The maximum for these offences is 5 years where the offender is under 18 (Sexual Offences Act 2003, s. 13), but strict liability as to age applies nonetheless.

${ }^{42}$ For a survey showing that over $20 \%$ of Crown Court cases have a strict liability element, and that a further $20 \%$ impose strict liability together with a due diligence defence (to be established by the defendant), see Ashworth, A., \& Blake, M. (1996). The presumption of innocence in english criminal law. Criminal Law Review, 306.

43 The degree of fault is relevant for sentencing purposes, and the court may have to hold a form of presentence hearing if the defence disputes the prosecution's case on this issue: cf. Lester (1975) $63 \mathrm{Cr}$ App R 144 with G. [2006] Crim.L.R. 930. 
blame? Or does this controversy reach further, so as to suggest that it is the criminal law's traditional indicators of blame that are inadequate (intention, knowledge, recklessness), and that on some issues it is morally and socially appropriate to convict and punish without proving one of those indicators because the factual situation was such that the person ought to have known what to do and what not to do?

What reasons lie behind the spread of strict liability? In relation to sexual offences and the question of age, the policy is clearly one of protecting young people from sexual predation. The pressure of demands for public protection here is thought to justify conviction on the grounds of incapacitation even in the absence of blameworthiness. ${ }^{44}$ One difficulty is that, as this policy is incorporated in the Sexual Offences Act 2003, it applies equally in respect of young defendants: so if a 15-year-old boy is misled by a 12-year-old girl into thinking that she is 15 too, strict liability applies nonetheless because the girl is actually under $13 .{ }^{45}$ By way of contrast, the spread of strict liability in those so-called regulatory offences that have only financial penalties for failing to submit returns or otherwise to comply with regulations may result from challenges (a) and (c), emphasising the cost of having to assemble and present evidence relating to fault. Insofar as the penalty and the stigma of conviction are low, it is thought acceptable to have the kind of streamlined process that strict liability offers, smoothing the prosecutor's path. At best, however, that is a public interest argument that concedes the main issue, namely that punishment and blameworthiness are only contingently connected. In so doing it uncouples the link between blameworthiness and punishment. Only the culpable deserve to be punished, and the public censure and hard treatment involved in punishment are unjustifiably imposed if blame is not established. ${ }^{46}$

It follows from this argument that strict criminal liability is not to be welcomed, in general. It should be regarded as exceptional and in need of strong justification, particularly where the offence is serious. Whether there are sufficiently strong economic arguments in favour of strict liability for summary offences enforcing regulation is a different question, ${ }^{47}$ particularly since the availability of negligence liability as a middle way means that it is not a choice between strict liability and full mens rea. There is a strong argument for confining criminal liability to offences that require fault, and of creating a separate category of MAPs (Monetary Administrative Penalties), as recommended by the Macrory Report (2006). ${ }^{48}$ Any such proposal raises further questions about decisions to allocate offences to the criminal courts or to MAPs, and safeguards for the rights of defendants, but it is important that such alternatives be considered fully. On a broader canvas, strict liability offences are but one manifestation of the over-extensiveness of the criminal law: the development of constructive crimes and of crimes that fail to abide by the correspondence principle must be noted, even if the growth of strict liability offences is the most egregious example of this trend.

\footnotetext{
44 Ashworth, A. (2004a). Criminal justice reform: Principles, human rights and public protection. Criminal Law Review, 516-532.

45 G. [2006] Crim.L.R. 930.

46 See the essays in Simester, A. P. (Ed.) (2005). Appraising strict liability. Oxford: Oxford University Press. esp. chap. 2 (by Simester) and chap. 3 (by Gardner).

47 Cf. the essays in Simester (ibid) with Hawkins, K. (2002). Law as last resort: Prosecution decisionmaking in a regulatory agency. Oxford: Oxford University Press.

48 Macrory, R. B. (2006). Regulatory justice: Making sanctions effective (November), esp. chap. 3.
} 


\section{Greater Incentives to Plea Guilty}

Like strict liability, the idea of incentives to plead guilty is not new. ${ }^{49}$ However, the final quarter of the last century saw an acceleration of the trend to provide incentives for trialavoidance. The practice of giving a discount of up to a third off custodial sentences for pleading guilty developed through the twentieth century, ${ }^{50}$ and in 1994 it was decided to put it into statutory form. ${ }^{51}$ This legislative encouragement to reduce sentence for those pleading guilty has now been reinforced by detailed guidelines on the matter, issued by the Sentencing Guidelines Council. ${ }^{52}$ The guidelines set out a sliding scale of discounts, running from a maximum of one-third for entering a guilty plea at the first reasonable opportunity, to a much smaller reduction of up to $10 \%$ for a last-minute change of plea. The guidelines also make it clear that an early guilty plea may justify reducing a custodial sentence to a community sentence. To these powerful incentives should now be added the system of advance indication of sentence, introduced into magistrates' courts by Schedule 3 to the Criminal Justice Act 2003 and then introduced into the Crown Court by judicial decision. ${ }^{53}$ In essence, a defendant who has entered a plea of not guilty may request from the court an indication of the highest sentence it would impose (i.e., before taking account of any personal mitigation) if the plea were changed to guilty. The court is not compelled to give such an indication, but if it does, both that court and subsequent courts are bound by it.

What are the implications of these developments? The purpose is to dispense with trials that are deemed unnecessary, an objective shared by many continental systems that had, until recent years, set themselves against guilty pleas and incentives to forego trial. ${ }^{54}$ The English initiatives aim to ensure that all those who are guilty plead guilty, and do so at the earliest stage of the process, and the statistics indicate some success in this direction. Thus, comparing the proportion of guilty pleas in 1996 with those in 2002, we find that for males aged 21 at the Crown Court the rate has increased from $73 \%$ to $79 \%$ for offences of violence, from $91 \%$ to $94 \%$ for burglary, from $83 \%$ to $92 \%$ for thefts, and from $83 \%$ to $88 \%$ for fraud and forgery. The only exception is the slight fall in the percentage of those charged with sexual offences who plead guilty, from $64 \%$ to $61 \% .{ }^{55}$ That category apart, the guilty plea rate is high (it is even higher in the magistrates' courts) and it is increasing. It can be anticipated that the effects of the new guidelines and of advance indication of sentence will be to confirm and possibly to enhance this trend. Thus the implications for prosecutors are positive, in the sense that they have an additional force working in favour of conviction. For defendants who have an arguable case, however, the implications are negative. Any right to put the prosecution to proof is heavily diluted by the incentive to

\footnotetext{
49 McConville, M., \& Mirsky, C. (2005). Jury trials and plea-bargaining: A true history.

50 Cf Thomas, D. (1979). Principles of sentencing. London: Heinemann, pp. 50-52; Cross, R. (1981). The english sentencing system (3rd ed.). London: Butterworths, pp. 115-119.

51 Criminal Justice and Public Order Act 1994, s. 48, subsequently amended and now re-enacted at s. 144 of the Criminal Justice Act 2003.

52 Sentencing Guidelines Council, Reduction in Sentence for a Guilty Plea (London: Sentencing Guidelines Council, 2004).

53 Goodyear [2005] 3 All ER 117.

54 For discussion of recent measures in France, Italy and elsewhere, see Weigend (above, n. 15).

55 Criminal Statistics England and Wales 1996, Table 7E, and Criminal Statistics England and Wales 2002, Table 4D.
} 
plead guilty, and to this extent the presumption of innocence is compromised. ${ }^{56}$ The incentive is so substantial that defendants with an arguable defence (e.g., on whether a taking was dishonest, or whether driving was dangerous rather than merely careless) may be persuaded to 'cut their losses' and plead guilty, especially if there is the prospect of a significantly lower or even non-custodial sentence.

What reasons lie behind the increased incentives for pleading guilty? The Sentencing Guidelines Council gave three reasons for the incentives - the importance of expediting the criminal justice process, the saving of costs, and the sparing of victims from anxiety about the prospect of having to give evidence. ${ }^{57}$ The first and second of these reasons follow the economic arguments of challenges (a) and (c): criminal trials are now an expensive commodity, and only if they are reserved for truly contested cases can the system function efficiently. Overall cost is a factor, but so is the shortage of judges, court buildings and so forth. Relatively little attention has been paid to the risk that innocent defendants will be tempted to plead guilty by the size of the discount offered and reinforced by their lawyer's advice. The Home Office has recognized the fact that this will put great pressure on innocent people, ${ }^{58}$ and it is unclear whether the involvement of the court (magistrates, judge) rather than simply the defendant's lawyer will be productive of greater or less pressure. In the United States some jurisdictions insist on direct dialogue between the judge and the defendant where a guilty plea has been entered, in an attempt to assess the defendant's reasons for plea, but the issue of possible safeguards appears not to have been taken far in this country. Questions must therefore be raised about the possibly coercive effects of increased incentives, and whether they undermine the presumption of innocence. Moreover, there is reason to doubt whether defence lawyers always protect defendants by advising them fully as to their rights, their prospects, and the likely consequences of a guilty plea. Past research has suggested that the practice of defence lawyers may not furnish an adequate safeguard against abuse. ${ }^{59}$ Trial-avoidance initiatives should not be welcomed into the English system without further research into their effects on the decision-making of defendants.

\section{Greater Use of Preventive Orders}

Strong measures in the name of public protection have long been possible in the penal system. The latest preventive measure of this kind, the indefinite sentence of 'imprisonment for public protection', casts the net more widely than any previous dangerousness sentence, and may well result in as many as one-third of the prison population serving indefinite sentences by $2012 .^{60}$ Our focus here, however, is on a different type of preventive sentence - the kind of preventive orders that courts may add to the sentence

\footnotetext{
56 On this and other aspects of the guilty plea discount, see Ashworth, A. (2005). Sentencing and criminal justice. Cambridge: Cambridge University Press, pp. 163-173.

57 Above n. 25, para. 2.1. Although victims may be deprived their day in court and angered by the lower penalty awarded.

58 Home Office, Justice for All (London: HMSO, 2002) paras. 4.41-4.44.

59 Baldwin, J. (1993). The role of legal representatives at the police station. London: HMSO; McConville, M., \& Hodgson, J. (1993). Custodial legal advice and the right to silence. London: HMSO.

60 See further Ashworth (above, n. 56), 210-218, and the Court of Appeal's guidance in Lang [2006] 2 Cr. App. R. (S) 13; for the statistics, see Rose, D. 'Locked up to make us feel better' (2007) New Statesman, 19 March.
} 
(or impose without a conviction), the number of which has increased considerably. ${ }^{61}$ Some preventive orders, notably disqualification from driving, are long established and indeed may often be regarded as the primary penalty for road traffic offences. Since 1986 there has been a power to disqualify a person from acting as a company director, introduced by the Company Directors Disqualification Act 1986. Of greater interest here is the power (or, for certain offences, the duty) to disqualify a person from working with children. ${ }^{62}$ The Court of Appeal has held that this is not a penalty but a preventive measure: the Court controversially reached this conclusion by arguing that, since the order can be made on a person pleading not guilty by reason of insanity, no conviction is necessary for it, and the result of this finding was that the order can be imposed retrospectively (i.e., for conduct occurring before the power was introduced). ${ }^{63}$ The Strasbourg Court has held that, so long as preventive orders are not too onerous, they are not subject to the same restrictions as penalties. ${ }^{64}$ Among the other preventive orders are travel restriction orders, football banning orders and exclusion from licensed premises orders. ${ }^{65}$ But English law has taken a step further, and has introduced a number of preventive orders that need not be made when sentencing an offender after conviction, but can be made on application to a court (without the need for a conviction). Included among these are the ASBO, already discussed in part 4 above; the sexual offences prevention order, to be made if a court, having taken evidence, is satisfied that this is necessary to protect others from serious sexual harm; and the risk of sexual harm order, to be made if a court, satisfied that a person has twice engaged in sexually explicit communications with children, holds that it is necessary to protect children from physical or psychological harm. ${ }^{66}$

The implications of these developments are considerable: in part 4 above we showed how the hybrid civil-criminal procedure is designed to remove various procedural rights of the defendant, but another feature is the reach of the orders. Not only may convicted offenders be subjected to negative conditions for long periods under preventive orders, but also persons who have not been convicted of any relevant offence may be subjected to restrictive conditions, suffer the stigma of the order and the adverse effects consequent on it, such as, for example, loss of employment. Sanctions for the breach of preventive orders are tough, and may involve imprisonment. For those orders that can be made without conviction, this gives rise to the same concerns as those already discussed in connection with hybrid civil-criminal orders - the crucial stage is the (civil) process of reviewing the evidence and deciding what restrictions to impose, and it is breach of those restrictions that can lead to a substantial sentence. Most of these orders can also be made by a court on conviction but even then, not being penalties, they do not count as part of the sentence. ${ }^{67}$

\footnotetext{
61 For fuller details of the range and scope of these preventive orders see Ashworth (above, n. 56) 335-340.

62 Criminal Justice and Court Services Act 2000, s.28.

63 Field and Young [2003] 2 Cr App R (S) 175, criticised by Ashworth, A. (2004b). Social control and antisocial behaviour order: The subversion of human rights? Law Quarterly Review, 120, 263-291.

64 Compare Welch v. United Kingdom (1995) 20 E.H.R.R. 247 (confiscation order is a penalty, because it may deprive a person of substantial amounts of property) with Ibbotson v. United Kingdom (1999) 27 E.H.R.R. CD332 (registration as a sex offender is not a penalty, because obligations are not onerous).

65 For discussion, see Ashworth (above, n. 28), 335-340.

66 For the last two, see Sexual Offences Act 2003, sections 104 and 123, discussed by Shute, S. (2004). New civil preventative orders: Sexual offences prevention orders, foreign travel orders and risk of sexual harm orders. Criminal Law Review, 417-440.

67 Von Hirsch, A., \& Wasik, M. (1997). Civil disqualifications attending conviction: A suggested conceptual framework. Cambridge Law Journal, 56, 559.
} 
A major reason for this development is public protection - the desire to reduce risk to citizens by restricting the movement of potentially dangerous people and by increasing surveillance and reporting. What was formerly known as sex offender registration, now notification orders under the Sexual Offences Act 2003, require the offender to register name, address and other personal details with the police, and to notify any changes within 3 days. The rationale is that the police can monitor movements, and if any sex offences are reported in the area, they know which ex-offenders live locally. ${ }^{68}$ This protective rationale is linked to challenge (d), arguing that the criminal trial is not the only appropriate forum for imposing such restrictions. However, the concern is that the factual basis should be proved at a hearing with the safeguards of criminal proceedings, and the restrictions should be proportionate to the degree of apprehended risk (which, in turn, includes the seriousness of any anticipated offences). ${ }^{69}$

Whether such developments should be welcomed depends on the strength of the procedural safeguards, ${ }^{70}$ and on the true extent of the protection. In relation to sex offences, as in some other spheres, there is little evidence of the efficacy of preventive orders. Reconviction studies of sex offenders suggest that those emerging from long-term imprisonment usually have lower than average prospects of reconviction, and yet that knowledge about sexual offending is so patchy that further detailed studies are needed before firm assertions can be made. ${ }^{71}$ Even if the protective effect of these measures were to be established, there is a need to attend to the procedural safeguards. Some decisions by the government and courts seem to indicate that the objective should be to circumvent or minimize safeguards wherever possible; that calls into the question the purpose of having the normal safeguards for trials and for sentences.

\section{Implications of the Changes}

\section{The Criminal Law and the Modern State}

Before we begin to consider the role of the criminal law in the modern state, a moment's historical reflection is called for. Although the paper plots significant changes in the nature and scope of the criminal law, it would be a mistake to consider the criminal law and procedure as immutable fixtures of our legal landscape. A longer historical analysis would reveal that the present changes are hardly unprecedented. Steiker, for example, has documented historical instances of a blurring of the criminal/civil law divide, not least through the use of punitive damages in tort and in the development of compensation as a criminal

\footnotetext{
${ }^{68}$ It is notable that in America sex offender registers are freely accessible on the web allowing members of the public to check on their neighbours. See for example the information posted by the Washington State Sex Offender Information Center at http://www.ml.waspc.org/

69 Though this presumes that it is possible accurately to calculate a future risk in such a way as to weigh the proportionality of the present burden.

70 Some scholars have argued for the development of a procedural 'middle ground' apposite to the particular demands thrown up by preventive and hybrid orders. See discussion in Steiker, C. (2002). Civil and criminal divide. In Dressler (Ed.), Encyclopedia of crime and justice (p. 163). New York: Macmillan.

71 Hood, R., Shute, S., Feilzer, M., \& Wilcox, A. (2002). Sex offenders emerging from long-term imprisonment: A study of their long-term reconviction rates and of parole board members' judgements of their risk. British Journal of Criminology, 42, 371-394.
} 
sanction. ${ }^{72}$ Nor is the use of administrative sanctions entirely new. But the examples given in this paper of recent deviations from the paradigm of criminal law and the criminal trial in England and Wales raise the important question: what do these challenges say about the role of the criminal law in the modern state?

The previous seven parts of this paper have shown that what might be termed a fulldress criminal trial is increasingly regarded as an expensive luxury, to be confined to really serious crimes. Other provisions are being made for the imposition of sanctions, and a growing body of actually or potentially coercive measures stands outside the traditional criminal process. The two major trends are diversion and downgrading, the former including the use of fixed penalties, the creation of hybrid procedures and the spread of preventive orders, and the latter including the greater use of summary trials and greater incentives to plead guilty. Within the criminal law itself the increase in offences of strict liability (mostly, but not all, carrying low penalties) also challenges the paradigm. Yet all these changes have taken place against the background of a steep increase in the number of criminal offences and a steep increase in the severity of penal measures, notably in the use of imprisonment (the prison population is now at its highest ever level, just over 80,000). This suggests a volatility in the English criminal law which, we argue, cannot easily be uncoupled from changes in the nature of the state and the ways in which it seeks to deploy (and in so doing deform) one of its most powerful tools of governance. Debates about the changing role of the state are sophisticated and complex. ${ }^{73}$ In what follows we delineate just three particularly prominent manifestations of the modern state that might begin to explain the ways in which the function of the criminal law in England and Wales is changing. For convenience we group these manifestations under three broad headings: the regulatory state, the preventive state, and the authoritarian state. These labels are intended less to describe different kinds of state than the over-development of particular state functions. These functions are hardly new: the claim made here is that they have developed in ways that significantly alter and even distort how the English state governs. Nor are these three classifications entirely separable: prevention is often carried out using regulatory strategies and authoritarian impulses often underpin prevention. They are, however, sufficiently distinct to be a useful basis for analysis.

\section{The Regulatory State}

The regulatory state is a tag widely adopted by political scientists to describe the withdrawal of the state from the active delivery of services ('rowing') to their direction ('steering'), a withdrawal prompted by the proposition that states govern more effectively at a distance. ${ }^{74}$ Whether and to what extent the impetus to regulation has, in practice, effected a withdrawal by the state, even in those western jurisdictions where it is most pronounced, is doubted by those who observe that the privatisation of services and the

\footnotetext{
72 Steiker, C. (2002). Civil and criminal divide. In Dressler (Ed.), Encyclopedia of crime and justice. New York: Macmillan.

73 Garland, D. (1996). The limits of the sovereign state: Strategies of crime control in contemporary society. British Journal of Criminology, 36, 445-471; Hood, C. (1998). The art of the state: culture, rhetoric, and public management. Oxford: Oxford University Press; Shearing, C. (2001). Punishment and the changing face of governance. Punishment and Society, 3, 203-220; Loader, I., \& Walker, N. (2004). State of denial? Rethinking the governance of security. Punishment and Society, 6, 221-228.

74 Osborne, D., \& Gaebler, T. (1992). Reinventing government: How the entrepreneurial spirit is transforming the public sector. New York: Penguin.
} 
failures of self-regulation has provoked ever greater state regulation. ${ }^{75}$ Given that moves to regulatory governance of the 'market society' were prompted by the economics of neoliberalism and Hayekian demands for a minimal state, it is particularly ironic that they appear to have resulted in more government intervention not less. ${ }^{76}$

A prominent feature of regulatory strategies is their acceptance of the normality of crime: hence Felson's well known characterization of crime as a normal social 'fact of everyday life'. ${ }^{77}$ This worldview tends towards a larger culture of 'managing crime' rather than responding to it as aberrant or to be suppressed. ${ }^{78}$ Important here is the influence of neo-liberal economics in characterising criminals not as wrongdoers but as rational actors motivated, like everyone else, less by reference to norms than by the desire to maximize their own utility. ${ }^{79}$ It follows that it is possible to manipulate choices by changing the opportunity costs of decision-making. Providing greater incentives to plead guilty is just one such example of economic analysis in action: the sentence discount is offered to encourage the rational calculator to change plea. Economic analysis affects thinking about crime itself, regarding it less as a moral wrong than as a calculable cost to be averted, whose losses can be recovered through restitutionary payments or otherwise amortised. Thus where diversion has a greater likelihood of enabling offenders to make good the losses they have inflicted, and where this can be done more cheaply and without a higher reconviction rate, it is to be preferred over conventional punishment. This managerialist tendency is particularly dominant at the lower end of the tariff where the claim to normality is most plausible. Here, censure and hard treatment become less appropriate than the manipulation of costs or disincentives (hence penalty notices for disorder).

The normalization of crime permits a routinization of crime control that licences the removal of lesser offences from the hallowed bastions of the criminal trial to the instrumental channels of civil and administrative law. Consequent upon this routinization is a diversification of procedural channels and means of control. Even within the criminal process, economic analysis has regard to the costs of procedural safeguards and subjects their necessity to rigorous scrutiny rather than accepting them as entrenched facets of a just system. ${ }^{80}$ Economic analysis also stands behind the so-called New Public Management (NPM) that evaluates public services less by the quality of their procedure or output than the economy and efficiency of service delivery. ${ }^{81}$ Greater use of fixed penalties, of plea bargaining, and summary trials in England and Wales might all be seen as examples of managerialist techniques that sacrifice principle and values for effectiveness (where

\footnotetext{
75 Moran, M. (2003). The British Regulatory State-High Modernism and Hyper-Innovation. Oxford: Oxford University Press.

76 Levi-Faur, D. (2005). The global diffusion of regulatory capitalism Annals of the American Academy of Political and Social Science, 598, 12-32: Preface p. 6.

77 Felson, M. (2002). Crime and everyday life. London: Sage.

78 Braithwaite, J. (2000). The new regulatory state and the transformation of criminology. In Garland \& Sparks (Eds.), Criminology and Social Theory. Oxford: Oxford University Press.

79 Eide, E. (2000). Economics of criminal behaviour. In De Geest (Ed.), Encyclopedia of law and economics. Ghent: Edward Elgar, p. 345.

80 Zedner, L. (2006). Opportunity makes the Thief-Taker: The influence of economic analysis on crime control. In Newburn \& Rock (Eds.), The Politics of Crime Control. Oxford: Oxford University Press.

81 Hood, C. (1998). The art of the state: culture, rhetoric, and public management. Oxford: Oxford University Press.
} 
effectiveness is measured more by speed and economy than achieving justice). Related to NPM is an 'audit culture ${ }^{, 82}$ that measures service delivery according to quantifiable throughput and so puts pressure on criminal justice personnel to hasten the dispatch of cases. Again penalty notices for disorder and the greater use of strict liability are prime examples of the privileging of pace over process.

The rise of the regulatory state might have been expected to diminish the state's direct exercise of sovereign power over its subjects through the engine of the criminal law. To a certain extent this shift can be observed in the English case by its growing recourse to civil, administrative, and other regulatory mechanisms in place of exercising the power to punish. It can also be seen in the state's apparent willingness to govern at a distance, imposing policing duties on local authorities, housing associations, landlords, and even on parents who must, for example, ensure that their offspring accord with the restrictions imposed upon them by ASBOs. On the other hand it is not clear that attempts to deflect responsibility for governance or to induce self-governance in the population have resulted in less direct government involvement in attempts to control crime through law-witness the rampant programme of criminalization that has characterized the past decade. ${ }^{83}$ Arguably, therefore, regulation has proved to be less about withdrawal of the state than the ushering in of a period of hyper-activity marked by legislative frenzy; an expanding apparatus of control; and a colonizing impulse quite at odds with the minimalism to which the regulatory state pretended.

\section{The Preventive State}

Our second classification is the preventive state, a term originating in North American legal literature to describe a temporal shift in state governance from managing the present to managing (or seeking to manage) the future. ${ }^{84}$ The historic orientation of the criminal justice system towards reactive policing and post-hoc punishment is overlaid by a proactive, preventive rationale that seeks to avert harms before they occur. A prime example of this trend in England and Wales is the introduction of Control Orders under the Prevention of Terrorism Act 2005 whose heavy restrictions upon the liberty of those suspected of involvement in terrorist activity are said to be justified on the grounds of averting possible catastrophic harm. The preventive state, like the regulatory state, is heavily influenced by economic analysis. It too is dominated by a consequentialist mode of reasoning that privileges efficacy, economy, and outcome over justice. ${ }^{85}$ Prime examples of this consequentialist orientation are risk averting orders such as Sexual Offences Prevention Orders and Risk of Sexual Harm Orders under the Sexual Offences Act 2003. Both orders depart from retributive, proportionate attribution of responsibility in favour of risk

\footnotetext{
82 Power, M. (1997). The audit society: Rituals of verification. Oxford: Oxford University Press.

83 Above, n. 26.

84 Steiker, C. (1998). The limits of the preventive state. Journal of Criminal Law and Criminology, 81, 771-808; Janus, E. (2004). The preventive state, terrorists and sexual predators: Countering the threat of a new outsider jurisprudence. Criminal Law Bulletin, 40, 576.

85 This is consistent with Feeley's observation of a larger 'trend throughout the twentieth century that moved law further along a continuum, away from a concern with morality and towards policy.' Feeley, M. (2004). Actuarial justice and the modern state. In Bruinsma, Elffers, \& de Keijser (Eds.), Punishment, places, and perpetrators: Developments in criminology and criminal justice research (p. 64). Devon, Cullompton: Willan Publishing.
} 
aversion in respect of wrongs not yet committed. ${ }^{86}$ The necessary corollary to the preventive state is the declining centrality of responsibility and attribution of desert, unless we can say that these punishments are in some sense 'pre-deserved' ${ }^{87}$ Failing this, it is doubtful whether the undoubted burdens imposed by preventive measures can be justified. Resort to the de-moralized language of prevention does not mean that a measure ceases to be stigmatic, burdensome, or punitive.

Aside from economic modelling, a larger preoccupation with risk and public protection stands behind the rise of the preventive state. ${ }^{88}$ Increasingly assertive claims about the reliability of risk assessment tools, the growing political acceptability (more pronounced still in the United States) of actuarial calculation as grounds for pre-emptive intervention, and the dominance of dangerousness as a ground for incapacitation are all particularly influential at the upper end of the tariff. ${ }^{89}$ Lower down the tariff where the inhibitions that cling to the imposition of grave long-term or indefinite restrictions do not apply, preventive orders abound. 'Disqualification from driving'; 'disqualification from acting as a company director'; 'disqualification from working with children'; 'travel restriction orders'; and 'exclusion from licensed premises orders' are just a few of the preventive orders that now proliferate. ${ }^{90}$ Many preventive orders are civil orders or hybrids that blur the boundaries of the criminal/civil divide and signal a larger change in the architecture of security. ${ }^{91}$ Although prevention is often licensed in the name of the gravest security threats such as terrorism, this licence percolates down tariff to permit a blurring of the criminal process also in respect of everyday crimes and nuisance (as in the case of ASBOs). ${ }^{92}$

Another important manifestation of the preventive state is the bid to control future behaviour through strategies of self-governance, 'responsibilisation', 93 or what Crawford has termed 'contractual governance'. ${ }^{94}$ Contractual governance is the attempt to foster compliance through contractual arrangements that rely upon eliciting consent from those upon they are imposed; that are concerned more with the distribution of responsibilities and obligations in respect of future conduct than past; that treat the parties as rational selfmaximizers (here again the influence of economic analysis is clear) who will exercise choice voluntary to avoid the consequences of breach; and that operate upon the

${ }^{86}$ Shute, S. (2004). New civil preventative orders: Sexual offences prevention orders, foreign travel orders and risk of sexual harm orders. Criminal Law Review, 417-440; Morse, S. J. (1998). Fear of danger, flight from culpability. Psychology, Public Policy and Law, 4, 250-267.

87 New, C. (1992). Time and punishment. Analysis, 52, 35-40; Statman, D. (1997). The time to punish and the problem of moral luck. Journal of Applied Philosophy, 14, 129-135.

88 Zedner, L. (2007a). Seeking security by eroding rights: The side-stepping of due process. In Goold \& Lazarus (Eds.), Security and human rights (pp. 257-275). Oxford: Hart Publishing.

${ }^{89}$ Monahan, J. (2006). A jurisprudence of risk assessment: Forecasting harm among prisoners, predators, and patients. Virginia Law Review, 92, 391-435. Feeley, M. (2004). Actuarial justice and the modern state. In Bruinsma, Elffers \& de Keijser (Eds.), Punishment, places, and perpetrators: Developments in criminology and criminal justice research (p. 64). Devon, Cullompton: Willan Publishing.

90 Ashworth, A. (2005). Sentencing and Criminal Justice. Cambridge: Cambridge University Press, pp. 335-340.

91 Günther, K. (2005). World citizens between freedom and security. Constellations, 12, 379-391 at 380.

92 Stuntz, W. (2002). Local policing after the terror. Yale Law Journal, 111, 2137-2194; Hillyard, P. (1994). The normalization of special powers from Northern Ireland to Britain. In Lacey (Ed.), A reader on criminal justice. Oxford: Oxford University Press.

93 Garland, D. (2001). The culture of control: Crime and social order in contemporary society. Oxford: Oxford University Press, at 124-127.

94 Crawford, A. (2003). Contractual governance of deviant behaviour. Journal of Law and Society, 30, 479-505. 
assumption of choice. ${ }^{95}$ The offender is thus offered the choice to accept a fixed penalty; the choice to plead guilty in reward for a lesser penalty; or the choice to abide by the terms of the proliferating quasi-contractual penalties in a bid to encourage self-regulation. Contractual governance also marks a move from the largely passive requirements of compliance with punishment towards the active exercise of responsibility for choices made about the minutiae of daily life, conduct, and movement. In the English case, this applies most obviously to ASBOs but can also be seen, for example, in some aspects of referral orders and youth offender contracts (under the Youth Justice and Criminal Evidence Act 1999). These contractual terms oblige offenders to engage in a form of self-policing of future conduct and demeanour for fear of substantial penalties for breach. As such they connote a significant shift in the criminal law away from the retrospective orientation of punishment for past actions towards what might termed 'future law'. ${ }^{96}$

\section{The Authoritarian State}

Running in parallel with these twin developments of the regulatory and the preventive state is a more worrisome trend still towards a more authoritarian state. In part this is fuelled by the rise of penal populism and a politics of law and order that cashes in on what von Hirsch has called the politics of resentment. ${ }^{97}$ Another recent moniker, the 'new punitiveness', ${ }^{98}$ attempts to capture the diminution of procedural protections for suspects, the rapid increase in mass incarceration, and the ready resort to retaliatory tactics like 'three strikes' laws in sentencing and punishments for breaching orders that go well beyond the original wrongdoing. Together these penal developments connote a willingness to resort to the criminal law, and to deploy its powers with little restraint, that at first sight directly gainsays the regulatory strategies discussed above. These authoritarian tendencies have their roots in the rise of populism in penal politics, fuelled in part by the willingness of politicians to take their lead from the media, in part by demands for greater public protection. ${ }^{99}$ Here too it is the gravest harms posed by dangerous violent and sexual offenders and the new scale and threat of terrorist activity that are invoked to justify harsher protective measures.

The demand for greater public protection in Britain also appears to be prompted by a backlash against the Human Rights Act that regards the culture and legislative effect of human rights protections as having unduly benefited defendants such that a rebalancing in favour of victims and the larger public is now needed. ${ }^{100}$ Although presented in positive terms as a move to increase public protection, it is arguable that the call for rebalancing is little more than a cover for punitiveness. Glaringly absent from the demand to rebalance in

\footnotetext{
95 Crawford, A. (2003). Contractual governance of deviant behaviour. Journal of Law and Society, 30, 479-505, pp. 489-491.

96 See Zedner, L. (2007b). Preventive justice or pre-punishment? The case of control orders. Current Legal Problems, 59.

97 Ashworth, A., \& von Hirsch, A. (Eds.) (1998). Principled sentencing: Readings on theory and policy. Oxford: Hart Publishing, pp. 417-420.

98 Pratt, J., Brown, D., Brown, M., Hallsworth, S., \& Morrison, W. (Eds.) (2005). The new punitiveness: Trends, theories, perspectives. Cullompton, Devon: Willan Publishing.

99 Ashworth, A. (2004a). Criminal justice reform: Principles, human rights and public protection . Criminal Law Review, 516-532.

${ }^{100}$ For discussion of the implications of this see, Ashworth, ibid., 529. See also Home Office, Rebalancing the criminal justice system in favour of the law-abiding majority: Cutting crime, reducing reoffending and protecting the public (London: HMSO, 2006).
} 
favour of the law-abiding public is any recognition that suspects and unconvicted defendants ought surely to be treated as law-abiding citizens. In part this backlash takes the form of active political campaigning against the Human Rights Act. ${ }^{101}$ In part it results in the more covert promotion of supposedly non-punitive civil orders that need not accord with the strictures of the criminal process and punishment. Perhaps the most notorious example is the infamous US decision in Kansas v. Hendricks, ${ }^{102}$ in which indefinite detention of a sexual offender was approved on the grounds that that it was civil commitment not punitive incarceration. ${ }^{103}$ Although we alluded earlier to the tendency of economic analysis to normalize crime by defining deviance down and to permit its control in alternate civil channels, we can see here that resort to civil procedure by no means necessarily results in less burdensome or less enduring restrictions. It is also the case that since criminalization is no longer to be regarded as the last resort when all other forms of social ordering have failed but rather as a routine system for managing disorder there is little inhibition in employing it liberally to regulate minor forms of offence (hence the proliferation of strict liability offences).

Punishment, the consequence and raison d'être of the criminal law, ${ }^{104}$ operates through the curtailment of the subject's rights. Under the modern state this curtailment was no untrammelled licence but a carefully calibrated and time-limited withdrawal of rights or, in Foucauldian terms 'economy of suspended rights'. ${ }^{105}$ It is the controlled and limited nature of modern punishment that distinguishes it from the excesses of the pre-modern punishments it replaced. Under the authoritarian state the twin demands of populist punitivism and public protection are taken to license extensive and indefinite controls or forms of containment that accord little value to the rights of the criminal subject and everything to the rights of the larger public. ${ }^{106}$ In England and Wales, life sentences, imprisonment for public protection, and extended sentences for sexual and violent offenders under the Criminal Justice Act 2003 all radically erode the rights of the offender on the ground of public protection from 'dangerous' individuals. The drastic diminution in the rights of those subject to these sentences is implicitly justified on the grounds that these are offenders whose actions are so heinous as to take them outside citizenship and the protections that ordinarily adhere thereto. Granted containment and incapacitation have long been accepted, though rarely discussed, justifications for punishment, ${ }^{107}$ what seems to be

\footnotetext{
101 For example, in a letter to John Reid on his taking office as Home Secretary Prime Minister Tony Blair suggested amending the Human Rights Act so as to require a 'balance between the rights of the individual and the rights of the community to basic security.' 'Revealed: Blair attack on human rights law' The Observer (Sunday May 14, 2006).

102 Kansas v Hendricks 521 U.S. 346 (1997).

103 Janus, E. (2000). Civil commitment as social control. In Brown \& Pratt (Eds.), Dangerous offenders: Punishment and social order. London: Routledge.

104 A relationship more transparent in the French droit penal or the German Strafrecht, than the English criminal law.

105 Foucault, M. (1979). Discipline and punish: The birth of the prison. Harmondsworth, Middlesex: Peregrine, p. 11.

106 MacCormick, N., \& Garland, D. (1998). Sovereign states and vengeful victims: The problem of the right to punish. In Ashworth \& Wasik (Eds.), The Fundamentals of Sentencing Theory. Oxford: Oxford University Press; Moran, M. (2003). The British Regulatory State-High Modernism and Hyper-Innovation. Oxford: Oxford University Press; Simon, J. (2001). "Entitlement to Cruelty": The End of Welfare and the Punitive Mentality in the United States.' In Stenson \& Sullivan (Eds.), Crime, risk, and justice. Cullompton, Devon: Willan Publishing.

107 Zimring, F. E., \& Hawkins, G. (1995). Incapacitation: Penal confinement and the restraint of crime. New York: Oxford University Press.
} 
different about present developments is that they lack any developed notion of proportionality with the risk posed. It is for these reasons that these developments recall, for Brown, the medieval device of 'civil death' that deprived its subject of all rights. ${ }^{108}$

It would be a mistake, however, to assume that the authoritarian state's deployment of the criminal law applies only at the upper end of the tariff. Lower down an institutionalized of intolerance of difference and a willingness to use the law as a stick with which to induce conformity with predetermined social norms is manifest most obviously in the civilcriminal law hybrid of the ASBO. Burney documents the wide-ranging powers now available in England to deal with the problem of anti-social behaviour and nuisance and observes that these powers are hardly less extensive than those available in respect of terrorist suspects but have attracted far less outcry or political debate. ${ }^{109}$ Moreover, the coercive provisions of an ASBO may be imposed without convicting the person of an offence. Arguably there can be no clearer evidence of the re-emergence of the authoritarian state than this willingness to criminalize and to subject to severe punishment the mere fact of defiance of the terms of a civil order. Contrasting this punitive response with the German policy of assigning low tariff offences to the category of administrative violations (Ordnungswidrigkeiten) reveals the divergent trajectories present in different jurisdictions. That the orientation of the criminal law and criminal process in many continental legal systems is appreciably less authoritarian than in England and Wales should thus provide a salutary warning against over-generalization.

The three models of state function (regulatory, preventive, and authoritarian) outlined here underpin and provide some partial explanations for the diverse changes in English criminal law and procedure that have been the subject of this paper. But can they help to answer the normative question of 'why criminal law'? Arguably yes, insofar as they reveal that criminalization cannot be understood solely as a matter of principle but as a politically charged set of decisions that result in a complex set of individual laws by which the state seeks to govern its subjects. Recognising the criminal law as an engine of government renders it impossible to separate its study from that of political theory and political economy. Whilst we might want to maintain a conception of criminal law as justice that is distinct from sovereign power, there is a powerful argument that a normative conception of the criminal law cannot be distinguished from a theory of good government. ${ }^{110}$

\section{Liberal Values and the Criminal Law}

The theme of this paper has been that the paradigm of the criminal law and the criminal trial is being eroded by the state as it pursues other agendas such as greater regulation, an emphasis on prevention, and an authoritarianism linked closely with penal populism and the demand for public protection. What, if anything, should restrain these tendencies? To some, the answer should be found in human rights protections. However, this is likely to prove a relatively unprofitable approach. It is true that European human rights law insists

\footnotetext{
108 Brown, M. (2005). Liberal exclusions and the new punitiveness. In Pratt, Brown, Brown, Hallsworth, \& Morrison (Eds.), The New Punitiveness: Trends, theories, perspectives. Cullompton, Devon: Willan Publishing, p. 284.

109 Burney, E. (2005). Making people behave: Anti-social behaviour, politics and policy. Cullompton, Devon: Willan Publishing, p. 164.

110 Dubber, M. D. (2005). The police power: Patriarchy and the foundations of American Government. New York: Columbia University Press, chap. 8.
} 
on certain procedural standards, and that much of the discussion in this paper has concerned criminal procedure. But there are few human rights protections that bear directly on the changes outlined in the first seven parts of the paper: the principle of allowing access to a court and an adversarial procedure is preserved by all forms of diversion and fixed penalties; the Strasbourg Court's insistence that the term 'criminal charge' has an autonomous meaning is an important principle, but it is not yet clear whether it will impinge on hybrid civil-criminal procedures; ${ }^{111}$ the presumption of innocence is declared in Article 6(2) of the European Convention, but there is some authority (albeit rather old) to the effect that this is not violated by either strict liability or the discount for pleading guilty; ${ }^{112}$ and the Strasbourg Court has developed a distinction between penalties and preventive orders that enables the latter to avoid the requirements of the Convention, such as non-retrospectivity. ${ }^{113}$ In this sphere, then, European human rights law may not have a great deal to offer. Its concern has always been to establish minimum standards of fairness, but it has ventured little into the criminal law itself ${ }^{114}$; and its more demanding procedural protections (relating to the privilege against self-incrimination and the principle of equality of arms, for example) do not impinge on the changes here described.

The challenges to the liberal model of criminal law and the criminal trial set out in the Introduction raise questions as to the efficacy, necessity, appropriateness, and effectiveness of the criminal law and its trial processes that cannot easily be put aside. If European human rights law appears not to have a significant restraining effect, what response should liberals who support some version of the model make? The criminal law purist might respond by arguing that to the extent that these challenges are warranted, they are best met by the development of parallel procedural channels, by the removal of 'quasi-crimes' from the criminal to an administrative process, or by the application of civil procedure. In these alternative procedural channels cases can be dealt with more cheaply, effectively, and appropriately, leaving the procedural requirements of the criminal law (as they pertain to the presumption of innocence, to the rights of the suspect, to evidence, to the standard of proof beyond reasonable doubt, and so on) to apply, undiluted and intact, to conduct that remains criminal. This would be to ensure that the criminal law concerns itself with a core of seriously wrong conduct, and that full procedural protections (consistent with Article 6 of the European Convention) are applicable in such cases. Minor wrongdoing and other anti-social conduct should be dealt with outside the criminal law, through streamlined procedures in administrative or civil law and without a criminal conviction or a severe sanction. The purist position goes further, since it insists that the censure inherent in a criminal conviction based on proof of fault, and liability to a significant punishment, may only be imposed following a criminal trial with the full protections available. Thus

\footnotetext{
111 In Clingham v. Chelsea and Kensington LBC; R. (McCann) v. Crown Court at Manchester [2003] 1 AC 787 the House of Lords held that the hybrid procedure for anti-social behaviour orders does not amount to a 'criminal charge', but the matter has not been tested in Strasbourg.

112 For discussion, see Ashworth, A. (2006). Four threats to the presumption of innocence. Evidence \& Proof, 10, 241-279.

113 See further Emmerson, B., Ashworth, A., \& Macdonald, A. (2007). Human rights and criminal justice (2nd ed.). London: Sweet \& Maxwell, chap. 16.

114 There are those who argue that strict liability contravenes the presumption of innocence in Article 6(2), but this is contestable, to say the least: compare Ashworth (above, n. 96), 252-257, with Tadros, V., \& Tierney, S. (2004). The presumption of innocence and the human rights act. Modern Law Review, 67, 402-434 and the counterblast in Roberts, P. (2005). Strict liability and the presumption of innocence: An expose of functionalist assumptions. In Simester (Ed.), Appraising strict liability. Oxford: Oxford University Press.
} 
'liability to a significant punishment' is a particularly powerful element here: the word significant opens up the possibility of some debate, but it ought surely to be accepted that any deprivation of liberty (e.g., through imprisonment) is significant. ${ }^{115}$ The liberal position should be that no person should be liable to imprisonment unless the law and the procedure conform to the model.

Critics would see a number of practical and theoretical difficulties with this, and three may be mentioned here. One is the argument that elements of strict liability may be socially justifiable in certain offences, and that a universal requirement of fault before conviction would deprive the law of significant preventive effect. The latter claim stands in need of empirical verification and cannot be accepted at face value. But, in any event, the liberal argument presented here is not that all convictions based on an element of strict liability are indefensible (as some would be prepared to argue) but the somewhat less demanding proposition that any conviction that renders a person liable to imprisonment without proof of fault as to all elements of the offence is objectionable in principle. ${ }^{116}$ No person should be deprived of liberty unless it is proved that they were at fault in committing the offence. The state should not be allowed to use its most punitive sanction against the individual unless fault is shown. ${ }^{117}$

A second counter-argument to the liberal position would raise questions about the proper response to breach of a preventive order. If it is accepted that preventive orders lie outside the criminal law, it would seem wrong in principle to maintain that the penalty for breach could be deprivation of liberty. The kind of hybrid procedure described in Part 4 above aims to circumvent this objection through legislative provisions that constitute breach of a civil order as a criminal offence. The counter-argument is therefore that the breach satisfies the requirement that there be a criminal offence and the availability of a defence of 'reasonable excuse' ensures that no defendant is convicted in the absence of fault. Deprivation of liberty is therefore fair. This is unconvincing, however: it decouples the civil proceedings and the subsequent enforcement proceedings when they should be viewed together. ${ }^{118}$ Thus it omits to mention that the civil order would have been made in civil proceedings, without all the safeguards of a criminal trial, and that in making the order the court is subject to few constraints. In effect, a civil court is making a personal criminal law for this defendant—which is objectionable in principle, because criminal laws should be general-and is doing so without according the human rights protections that

\footnotetext{
115 On this point the European Convention and its case-law is already strongly in line. Wherever proceedings involve a 'criminal charge', the defendant must be accorded certain rights. Whether the proceedings do involve such a charge is always a question for the court, looking at the substance rather than the form, the leading decisions make it clear that the possibility of imprisonment is a fairly conclusive reason to find that the proceedings are in essence criminal: see Engel v. Netherlands (1979) 1 EHRR 647 and Garyfallou AEBE v. Greece (1999) 28 EHRR 344, discussed in Emmerson, B., Ashworth, A. \& Macdonald, A. (2007). Human rights and criminal justice (2nd ed.) London: Sweet \& Maxwell, chap. 4.

116 For further argument, see Simester, A. P. (Ed.) (2005). Appraising strict liability. Oxford: Oxford University Press, chap. 2, and Ashworth, A. (2006). Principles of criminal law (5th ed.). Oxford: Oxford University Press, pp. 164-174.

117 The European Convention does not recognise such a fundamental right, but the Canadian Charter of Rights does: References re section 94(2) of the Motor Vehicle Act (1986) 48 CR (3d) 289.

118 See further Ashworth, A. (2004b). Social control and anti-social behaviour order: The subversion of human rights? Law Quarterly Review, 120, 263-291; Simester, A. P., \& Von Hirsch, A. (2006). Regulating offensive conduct through two-step prohibitions. In Von Hirsch \& Simester (Eds.), Incivilities: Regulating offensive behaviour. Oxford: Hart Publishing.
} 
should be respected. ${ }^{119}$ Moreover, this use of severe penalties for breach is a manifestation of the authoritarian state at its worst. The penalty of up to 5 years for breach is higher than that for racially aggravated assault and affray, for example, and the same as that for recklessly inflicting grievous bodily harm. Deprivation of liberty for breach is wrong in principle; potential deprivation of liberty for up to 5 years is absolutely indefensible in these circumstances.

A third counter-argument is that liberal concerns about incentives to plead guilty are overdone and unworldly. The practice of offering incentives to defendants for trial avoidance is now widespread across the Commonwealth, the United States and continental Europe. But even if there can be said to be a European consensus on the need for a guilty plea system, that does not conclude the issue of how substantial an incentive may be offered without violating the presumption of innocence. It is of deep concern that the English system now offers a reduction of up to one-third off the sentence-which may mean a community sentence rather than custody in some cases-and that this can now be combined with some form of advance indication of sentence from the judge or magistrates. On the one hand, there is public disquiet about the economic benefits to the criminal justice system being traded off too cheaply, with large discounts offered to defendants. On the other hand, the pressure that the system creates on innocent defendants or those with an arguable case is surely too great, much as the government and many judges play this down. In principle, the legal system should avoid offering inducements at decision-points that may already bear heavily on individuals. Limits are imposed on the extent to which the police can impose pressure to make a suspect confess, in terms of holding out inducements, and the Strasbourg Court has held that an offer to waive trial on payment of a fee should be free from 'constraint', a test that focuses on the amount of the inducement or penalty involved. This concedes that a small incentive should not be held to negative consent, since there are many life-situations in which people need a kind of prompt to do the right thing (i.e., to plead guilty if they are guilty). But where the incentive is substantial, such as a onethird sentence discount or a reduction from custody to a non-custodial sentence for pleading guilty, this may be so coercive as to negative consent and thus to violate the presumption of innocence. The difference is one of degree, so the assertion cannot be made with complete confidence. But any serious examination of the guilty plea discount in relation to the presumption of innocence and the concept of coercion must surely cast doubt on this aspect of the English system. ${ }^{120}$

There may be pragmatists who, sympathetic to some of the counter-arguments just set out, would argue that adapting the criminal law (and, it follows, the demands of criminal procedure) to meet the challenges it now faces is the best means to ensure that as much wrongdoing as is possible is retained within its precincts. Only a willingness to contemplate adaptation of criminal law and procedure will ensure that those accused of the most serious wrongdoing have the benefit of at least some of its protections. So one might contemplate a reduction of the scope of the hearsay rule and an expansion of reverse onus provisions, for example, as the price of ensuring that other human rights protections remain in full vigour. It is arguments such as these that underpin current debate about what possible alterations of criminal procedure, and in particular rules of evidence, might be

\footnotetext{
119 Ashworth, A., Gardner, J., Morgan, R., Smith, A.T.H., von Hirsch, A., \& Wasik, M. (1998). Neigbouring on the oppressive: The government's 'anti-social behaviour order' proposals. Criminal Justice, 16, $7-14$.

${ }^{120}$ See further Ashworth, A. (2007). Plea negotiation, pragmatism and rights. In H. Koriath, et al. (Ed.), Festschrift für Heike Jung. Baden Baden: Springer Verlag.
} 
warranted in order to ensure that terrorist suspects are prosecuted in court rather than subjected to avowedly non-criminal containment in the community under Control Orders, or deportation. ${ }^{121}$ The current exclusion of intercept evidence is not required by human rights law and is not common in other countries, and admitting such evidence would help to facilitate the prosecution of those suspected of terrorist related activity (although some of the security services have opposed this in order to preserve the secrecy of their operations). It may seem strange to maintain that suspected terrorists have a 'right to be prosecuted', but what that means is that fairness demands their prosecution in court-even if it is politically necessary to alter some rules of evidence while remaining within human rights law-so as to ensure that fundamental protections are observed. These pragmatic arguments are not ones that we would accept, since they involve a sacrifice of principle on the basis of a political calculation about the costs and benefits of diminishing procedural protections that is open to considerable doubt. We would wish to see suspected terrorists tried without reducing procedural safeguards but with greater resources being put into the gathering of evidence (if that is deemed necessary) and the increased protection of security service personnel and information sources.

\section{Conclusion}

Conviction of an individual for an offence is the strongest form of condemnation of conduct that the state can muster. Conviction for an offence also opens the possibility of a coercive sentence, ordered by a court within the limits of what legislation permits. To justify the creation of a certain crime is therefore to justify the imposition of the censure of conviction and the imposition of a punishment. It is the special significance and gravity of these consequences, with all their legal and social implications, that supports the argument for safeguards in the shape of the procedural requirements of human rights law-the presumption of innocence, the need for proper notice of the charge, adequate time and facilities for preparing a defence, state-funded legal assistance, the right to confront witnesses, the free assistance of an interpreter, the privilege against self-incrimination and various other rights. ${ }^{122}$

Yet we have shown how the existence of these human rights protections has stimulated the development of alternative channels of control that enable the state to avoid the more onerous procedural requirements that now apply to the criminal process. The panoply of preventive, civil, administrative, and hybrid orders introduced in England and Wales in recent years is to a large extent the consequence of just such an imaginative skirting of the burdens of the Convention. Given that the Human Rights Act does not appear to have been adequate to the task and may even have given rise to deliberate subversion of its provisions, two questions remain to be addressed. Under what political conditions do developments such as those described here occur? And what kinds of constitutional or democratic changes would be necessary to rein back these developments? Answers to these questions probably require both a macro level constitutional defence of the criminal law

\footnotetext{
121 See for example, Joint Committee on Human Rights-Twenty-Fourth Report Counter-Terrorism Policy and Human Rights: Prosecution and Pre-Charge Detention, HL Paper 240, HC 1576, (1 August 2006). The report includes "consideration of possible adaptations of the criminal justice system which are capable of facilitating the effective criminal prosecution of terrorist suspects in ways compatible with the UK's human rights obligations" at para 4.

122 These are some of the safeguards listed in Article 6(2) of the Convention or implied into Article 6 by the Court.
} 
and the further development (and formal adoption) of principles at the micro level of the criminal process.

Our defence of the liberal model of the criminal law and the criminal trial rests on the proposition that, at the level of justification, there is a necessary link between the censure of conviction, liability to (significant) punishment, and the need to respect the dignity of the individual defendant through the upholding of rights. To the extent that the developments outlined in parts 2-7 of this paper impinge on that model, they should be opposed. Where the boundaries of the criminal law and the criminal process are drawn should be consistent with the procedural protections provided. If the government is not prepared to extend full procedural protections to persons found responsible for certain behaviour, the corollary should be that the criminal process should not be used, and the penalties should remain at a low level-along the lines of Penalty Notices for Disorder, and certainly should exclude imprisonment. Such provisions would be part of a new tier of 'administrative offences': the government would still need to show that the conduct was sufficiently wrong to justify the imposition of a penalty, even if the penalty was a low one, and access to the criminal courts would be available for those who dispute liability. However, if the government wants it to be possible to imprison people for certain conduct, it should create fault-based criminal offences that penalise the conduct, operate under the protective mantle of the criminal process, and provide for proportionate penalties. This is not to suggest that governments or legislatures should be free to criminalize whatever conduct they want: our discussion in this paper assumes an adequate theory of the justifications for criminalization, of the kind developed by Doug Husak. ${ }^{123}$ Likewise the paper assumes an adequate theory of the justifications for state punishment, along the lines developed by desert theorists. ${ }^{124}$ It is not only the labelling of someone as an offender but more particularly liability to significant punishment, we have sought to argue, that makes the case for adherence to the liberal model of the criminal law and the criminal trial.

Acknowledgements The authors are grateful to Andrew von Hirsch, Victor Tadros and the participants at the British Academy Seminar 'Why Criminal Law?' (13 January 2007), in particular respondents Rowan Cruft and Stuart Green, for their comments.

\section{References}

Ashworth, A., \& Blake, M. (1996). The presumption of innocence in English Criminal Law. Criminal Law Review 306.

Ashworth, A., et al. (1998). Neigbouring on the oppressive: The government's 'Anti-Social Behaviour Order' proposals. Criminal Justice, 16, 7-14.

Ashworth, A., \& von Hirsch, A. (Eds.) (1998). Principled sentencing: Readings on theory and policy. Oxford: Hart Publishing.

Ashworth, A. (2004a). Criminal justice reform: principles, human rights and public protection. Criminal Law Review 516-532.

Ashworth, A. (2004). Social control and anti-social behaviour order: The subversion of human rights? Law Quarterly Review, 120, 263-291.

Ashworth, A. (2005). Sentencing and criminal justice (4th ed.). Cambridge: Cambridge University Press. Ashworth, A., \& Redmayne, M. (2005). The criminal process (3rd ed.). Oxford: Oxford University Press. Ashworth, A. (2006). Four threats to the presumption of innocence. Evidence and Proof, 10, 241.

\footnotetext{
123 As an indication of the direction likely to be taken in his forthcoming book, see Husak, D. (2004). The criminal law as last resort. Oxford Journal of Legal Studies, 24, 207-235.

124 E.g., von Hirsch, A., \& Ashworth, A. (2005). Proportionate sentencing: Exploring the principles. Oxford: Oxford University Press.
} 
Ashworth, A. (2006). Principles of criminal law (5th ed.). Oxford: Oxford University Press.

Baldwin, J. (1993). The role of legal representatives at the police station. London: HMSO.

Braithwaite, J. (2000). The new regulatory state and the transformation of criminology. In D. Garland, \& R. Sparks (Eds.), Criminology and social theory. Oxford: Oxford University Press.

Brown, M. (2005). Liberal exclusions and the new punitiveness. In J. Pratt, et al. (Eds.), The new punitiveness: Trends, theories, perspectives. Cullompton, Devon: Willan Publishing.

Burney, E. (2005). Making people behave: Anti-social behaviour, politics and policy. Cullompton, Devon: Willan Publishing.

Cohen, S. (1985). Visions of social control. Cambridge: Polity Press.

Crawford, A., (2003). 'Contractual governance' of deviant behaviour. Journal of Law and Society, 30, 479-505.

Cross, R. (1981). The English sentencing system (3rd ed.). London: Butterworths.

Dubber, M. D. (2005). The police power: Patriarchy and the foundations of american government. New York: Columbia University Press.

Duff, A., et al. (2004). Introduction: Towards a normative theory of the criminal trial. In A. Duff, et al. (Eds.), The trial on trial, volume one. Oxford: Hart Publishing.

Emmerson, B., et al. (2007). Human rights and criminal justice (2nd ed.). London: Sweet \& Maxwell.

Feeley, M. (2004). Actuarial justice and the modern state. In G. Bruinsma, et al. (Eds.), Punishment, places, and perpetrators: Developments in criminology and criminal justice research. Devon, Cullompton: Willan Publishing.

Felson, M. (2002). Crime and everyday life (3rd ed.). London: Sage.

Fionda, J. (1995). Public prosecutors and discretion: A comparative study. Oxford: Oxford University Press. Fionda, J. (2005). Devils and angels: Youth policy and crime. Oxford: Hart Publishing.

Foucault, M. (1979). Discipline and punish: The birth of the prison. Harmondsworth, Middlesex: Peregrine. Garland, D. (1996). The limits of the sovereign state: Strategies of crime control in contemporary society. British Journal of Criminology, 36, 445-471.

Garland, D. (2001). The culture of control: Crime and social order in contemporary society. Oxford: Oxford University Press.

Günther, K. (2005). World citizens between freedom and security. Constellations, 12, 379-391.

Hawkins, K. (2002). Law as last resort: Prosecution decision-making in a regulatory agency. Oxford: Oxford University Press.

Hillyard, P. (1994). The normalization of special powers from Northern Ireland to Britain. In N. Lacey (Ed.), A reader on criminal justice. Oxford: Oxford University Press.

Home Office (2002). Justice for all. London: HMSO.

Home Office (2006). Rebalancing the criminal justice system in favour of the law-abiding majority: Cutting crime, reducing reoffending and protecting the public. London: HMSO.

Hood, C. (1998). The art of the state: Culture, rhetoric, and public management. Oxford: Oxford University Press.

Hood, R., et al. (2002). Sex offenders emerging from long-term imprisonment: A study of their long-term reconviction rates and of parole board members' judgements of their risk. British Journal of Criminology, 42, 371-394.

Hoyle, C., \& Zedner, L. (2007). Victims, victimization and criminal justice. In M. Maguire, et al. (Eds.), The Oxford handbook of criminology. Oxford: Oxford University Press.

Husak, D. (2004). The criminal law as last resort. Oxford Journal of Legal Studies, 24, 207-235.

Janus, E. (2000). Civil commitment as social control. In M. Brown, \& J. Pratt (Eds.), Dangerous offenders: Punishment and social order. London: Routledge.

Janus, E. (2004). The preventive state, terrorists and sexual predators: Countering the threat of a new outsider jurisprudence. Criminal Law Bulletin, 40, 576.

Levi-Faur, D. (2005). The global diffusion of regulatory capitalism. Annals of the American Academy of Political and Social Science, 598, 12-32.

Loader, I., \& Walker, N. (2004). State of denial? Rethinking the governance of security. Punishment and Society, 6, 221-228.

MacCormick, N., \& Garland, D. (1998). Sovereign states and vengeful victims: The problem of the right to punish. In A. Ashworth, \& M. Wasik (Eds.), The fundamentals of sentencing theory. Oxford: Oxford University Press.

Macrory, R. B. (2006). Regulatory justice: Making sanctions effective. London: Duchy of Lancaster, November.

McConville, M., \& Hodgson, J. (1993). Custodial legal advice and the right to silence. London: HMSO.

Moran, M. (2003). The British regulatory state-High modernism and hyper-innovation. Oxford: Oxford University Press. 
New, C. (1992). Time and punishment. Analysis, 52, 35-40.

Osborne, D., \& Gaebler, T. (1992). Reinventing government: How the entrepreneurial spirit is transforming the public sector. New York: Penguin.

Power, M. (1997). The audit society: Rituals of verification. Oxford: Oxford University Press.

Pratt, J., et al. (Eds.) (2005). The new punitiveness: Trends, theories, perspectives. Cullompton, Devon: Willan Publishing.

Ramsay, P. (2004). What is anti-social behaviour? Criminal Law Review 908-925.

Roberts, P. (2005). Strict liability and the presumption of innocence: An expose of functionalist assumptions. In A. P. Simester (Ed.), Appraising strict liability. Oxford: Oxford University Press.

Roberts, P. (2006). Theorising procedural tradition: Subjects, objects and values in criminal adjudication. In A. Duff, et al. (Eds.), The trial on trial, volume two. Oxford: Hart Publishing.

Sentencing Guidelines Council (2004). Reduction in sentence for a guilty plea. London: Sentencing Guidelines Council.

Sentencing Guidelines Council (2006). Breach of a protective order (Consultation Guideline). London: Sentencing Guidelines Council.

Shearing, C. (2001). Punishment and the changing face of governance. Punishment and Society, 3, $203-220$.

Shute, S. (2004). New civil preventative orders: Sexual offences prevention orders, foreign travel orders and risk of sexual harm orders. Criminal Law Review 417-440.

Simester, A. P. (Ed.) (2005). Appraising strict liability. Oxford: Oxford University Press.

Simester, A. P., \& Von Hirsch, A. (2006). Regulating offensive conduct through two-step prohibitions. In A. Von Hirsch, \& A. P. Simester (Eds.), Incivilities: Regulating offensive behaviour. Oxford: Hart Publishing.

Simon, J. (2001). Entitlement to cruelty: The end of welfare and the punitive mentality in the United States. In K. Stenson, \& R. R. Sullivan (Eds.), Crime, risk, and justice. Cullompton, Devon: Willan Publishing.

Statman, D. (1997). The time to punish and the problem of moral luck. Journal of Applied Philosophy, 14, $129-135$.

Steiker, C. (1998). The limits of the preventive state. Journal of Criminal Law and Criminology, 81, $771-808$.

Steiker, C. (2002). Civil and criminal divide. In J. Dressler (Ed.), Encyclopedia of crime and justice. New York: Macmillan Reference.

Stuntz, W. (2002). Local policing after the terror. Yale Law Journal, 111, 2137-2194.

Tadros, V., \& Tierney, S. (2004). The presumption of innocence and the human rights act. Modern Law Review, 67, 402-434.

Thomas, D. (1979). Principles of sentencing. London: Heinemann.

Von Hirsch, A., \& Wasik, M. (1997). Civil disqualifications attending conviction: A suggested conceptual framework. Cambridge Law Journal, 56, 559.

von Hirsch, A., et al. (1999). Criminal deterrence and sentence severity: An analysis of recent research. Oxford: Hart Publishing.

Von Hirsch, A., \& Roberts, J. (2004). Legislating sentencing principles: the provisions of the Criminal Justice Act 2003 relating to sentencing purposes and the role of previous convictions. Criminal Law Review 639-652.

von Hirsch, A., \& Ashworth, A. (2005). Proportionate sentencing: Exploring the principles. Oxford: Oxford University Press.

Von Hirsch, A., \& Simester, A. P. (Eds.) (2006). Incivilites: Regulating offensive behaviour. Oxford: Hart Publishing.

Weigend, T. (2006). Why have a trial when you can have a bargain? In A. Duff, et al. (Eds.), The trial on trial, volume two. Oxford: Hart Publishing.

Williams, G. (1955). The definition of a crime. Current Legal Problems, 107-130.

Zedner, L. (2006). Opportunity makes the thief-taker: The influence of economic analysis on crime control. In T. Newburn, \& P. Rock (Eds.), The politics of crime control. Oxford: Oxford University Press.

Zedner, L. (2007a). Seeking security by eroding rights: The side-stepping of due process. In B. Goold, \& L. Lazarus (Eds.), Security and human rights (pp. 257-275). Oxford: Hart Publishing.

Zedner, L. (2007b). Preventive justice or pre-punishment? The case of control orders. Current Legal Problems, 59.

Zimring, F. E., \& Hawkins, G. (1995). Incapacitation: Penal confinement and the restraint of crime. New York: Oxford University Press. 